
\title{
3 Research Square \\ Factors that influence natural menopause onset in China: a cross-sectional study
}

\section{Xuming Wang ( 107967594@qq.com )}

Guilin Medical University

Huawei Gui

Wuhan fourth hospital

\section{Chunyan Yuan}

Fudan University Shanghai Cancer Center Minhang Branch Hospital

\section{Lijiang Liu}

Jianghan University School of Medicine

Jianguo Wei

Shaoxing People's Hospital

Helin Huang

Guilin Medical college

Zhaohui Qiu

Guilin medical college

\section{Xiaolu Yuan}

maoming people's hospital

\section{Research article}

Keywords: Age of onset, Epidemiologic factor, Menopause, Perimenopause

Posted Date: September 21st, 2020

DOI: https://doi.org/10.21203/rs.3.rs-59501/v1

License: (c) (1) This work is licensed under a Creative Commons Attribution 4.0 International License.

Read Full License 


\section{Abstract}

\section{Background}

This paper aimed to explore the average natural menopause age, the span of menopausal age, and the related factors that will probably affect the natural menopause age of Chinese women.

\section{Methods}

A large-scale random sampling of menopausal women aged 32-75 years in 18 provinces or municipalities throughout China was conducted using paper questionnaire surveys to investigate the menopause age, menarche age, fertility status, illness history, and living habits. The SPSS 24.0 software package was used to carry out $t$ test, chi-square test, logistic regression, and other statistical analyses.

Results

A total of 5852 questionnaires were collected. After excluding questionnaires having no menopause, questionnaires with incomplete or invalid information, and questionnaires that may directly affect the age of menopause, such as hysterectomy, oophorectomy, and other factors that may affect natural menopause, a total of 4426 effective questionnaires have been collected, and the average age of natural menopause was $49.49 \pm 3.67$ years old.

\section{Conclusion}

Factors that may affect the age of natural menopause are weight, menarche age, marital status, drinking tea or not (often and daily), eating supplements, oral contraceptive contraception, and safe contraception.

\section{Background}

Studies have shown that the occurrence and development of many diseases, including malignant tumors, are related to estrogen levels in women [1-3]. The menstrual cycle, a normal physiological activity in women, is accompanied by periodic changes of estrogen and progesterone. The cyclical activity of estrogen affects not only the reproductive system and fertility but also the occurrence and development of various reproductive and non-reproductive system tumors and non-tumor diseases, such as breast, endometrial, ovarian, gastric, and liver cancer, liver cirrhosis, and osteoporosis [4-19]. Therefore, the study of the average age of menopause and its influencing factors can play an auxiliary role in understanding and treating such diseases. Additionally, the main factor affecting female physiological estrogen levels is menopause. However, there is a lack of data on Asian women. These women have a different physiological response to body fat (see the differing standards of BMI for Asians), which may influence estrogen levels[20]. Therefore, this study aimed to determine the average age of physiologic menopause and the span of menopausal age in Chinese women to provide a reference for health care, disease prevention, and possible intervention related to women's estrogen levels during the perimenopausal period. 


\section{Methods}

\subsection{Participants}

Women aged 32-75 years who had already experienced natural menopause were recruited between January 2018 and February 2019 in 18 provinces and municipalities throughout China. They were recruited in community centers and were identified by clinicians with the following inclusion criteria: normal uterine status; no atypical endometrial hyperplasia or neoplastic lesions; intact ovaries; no cardiovascular, kidney, liver, and neurological diseases; no history of surgery; no history of hypothalamic diseases; and normal psychological status. Exclusion criteria included age below 32 or above 75 years, endocrine diseases (such as hyperthyroidism, diabetes mellitus, polycystic ovarian syndrome), and longterm hormone therapy ( $\geq 3$ months) or other medications that could possibly interfere with menopausal phenomena. We obtained informed consent from the participants by written or verbal and obtained approval from the Guilin Medical college ethics review committees to conduct this research.

\subsection{Study design and sampling method}

A multicenter cross-sectional study was performed. Women were surveyed using a self-administered questionnaire. They were recruited in community centers and identified by clinicians. Data included current age; age of menarche and of last menstrual period; weight; marital status; number of pregnancies; frequency of drinking tea, smoking, eating fruit, and taking dietary supplements such as the donkey-hide gelatin; vegetarian status; sleep quality; and contraceptive methods. Women who had experienced the last menstrual period at least 1 year prior were defined as menopausal.

\subsection{Statistical analysis}

Statistical analysis was done using SPSS 24.0 (IBM, Armonk, NY). Measured data were expressed as mean \pm SD; counted data were expressed by percentage (\%). Comparison between two samples was done using Student's t-test. Non-normally distributed data or data with uneven variance were analyzed using the rank sum test. In addition, chi-square test was used in this research. Multiple logistic regression models were used to analyze potential influencing factors. Statistical significance was set at $a=0.05, P$ $<0.05$.

\section{Results}

\subsection{Background data}

A total of 5,852 women were surveyed and completed the questionnaire, of whom 4,426 were effectively surveyed, with a valid completion rate of $75.6 \%$. The age range was $32-75(59.3 \pm 6.98)$ years old. All participants were menopausal. A total of 1426 women were excluded, including those who had surgical removal of ovaries or uterus, those with endocrine diseases (e.g., hyperthyroidism, diabetes, polycystic ovary syndrome), and those who received hormone therapy ( $\geq 3$ months) and other potentially interfering 
medication. Finally, 4426 naturally menopausal women under physiological conditions were analyzed. The maximum age of menopause was 65 years, and the minimum age of menopause was 32 years, with a mean of $49.49 \pm 3.67$ years. Based on the average age of menopause, we divided the survey sample into the younger menopause group ( $<45$ years old), the normal menopause group ( $45-55$ years old), and the older menopause group ( $>55$ years old).

\subsection{Natural menopause age}

The mean age of onset of natural menopause was $49.49 \pm 3.67$ years. Among the natural menopause population, there were 327 cases $(7.4 \%)$ of early menopause ( $<45$ years), 3927 cases $(88.7 \%)$ of normal menopause ( $45-55$ years), and 172 (3.9\%) cases of late menopause ( $>55$ years).

\subsection{Factors that influence menopausal age}

The distribution of early, normal, and late menopause and the possible influencing factors are shown in Table 1. Logistic regression analysis to determine which factors had a statistically significant influence on the age of menopause is shown in Table 2. Logistic regression analysis of relevant influencing factors of menopausal age is shown in Table 3.

The results of the chi-square test (Table 1) revealed that marital status, frequency of drinking tea, frequency of smoking, alcohol consumption, frequency of eating fruits, taking dietary supplements, sleep quality, and contraceptive method were statistically significant among the three groups, while the proportion of vegetarian habits had no significant difference.

Logistic regression analysis (Table 2) shows that body weight, age of menarche, marital status, tea drinking (often and daily), taking supplements, oral contraceptive use, and safe period contraception methods significantly influenced menopause age. However, fertility times, occasionally drinking tea, drinking wine, eating fruits, drinking milk, condom use, and ligation and intrauterine ring contraceptive methods showed no significant difference.

The results showed that for every increase in the number of pregnancies, the age of menopause was advanced by 0.71 years; an increase of $1 \mathrm{~kg}$ in body weight increased the age of menopause by 0.018 years; and the age of menopause of married women was delayed by 2.587 years compared with those unmarried. Compared with people who never drank tea, occasional tea drinking had little effect on the age of menopause. The menopause age of people who drink tea frequently was delayed by 0.863 years, while the menopause age of people who drink tea daily was delayed by 0.914 years. Compared with people who never take the donkey-hide gelatin supplements, the age of menopause in those who take supplements occasionally was delayed by 0.418 years, the menopause age of people who take regular supplements was delayed by 0.806 years, and the menopause age of people who take daily supplements was delayed by 1.548 years. Compared with people who had never used contraception, the age of menopause was 0.404 years earlier for those who use oral contraceptives and 0.603 years earlier for those who adopted safe period contraception. Logistic regression analysis demonstrated that body 
weight and age of menarche were predictive for menopausal age, and the fertility times are not correlated with menopausal age (Table 3).

\section{Discussion}

The results of this study suggest that the natural age of menopause in Chinese women is $49.49 \pm$ 3.67 years old, and factors that may affect the age of natural menopause include body weight, age of menarche, marital status, frequent tea drinking, dietary supplements, oral contraceptive use, and safe period contraception methods. Our research showed that weight may be related to the age of menopause, which is consistent with the report by other papers[21-24]. The age of menarche was significantly related to the age of menopause, similar to previous research in Norwegian women[25]. People with earlier menarche age have earlier menopause; those with later menarche age have relatively late menopause age. Delayed ovulation time and follicle exhaust time may lead some women to have later menopause age which may be correlated to later menarche age[21-24]. Due to the late menarche, the ovulation time is delayed, and the ovarian follicle exhaustion time is also delayed. Unexhausted follicles can continue to mature, secrete estrogen, and expel the ovum. Marital status, frequent tea drinking, dietary supplements, oral contraceptive, and safe period contraception were related to the age of menopause, which are also consistent with current reports [21-24, 26-28].

Researchers have shown that the number of pregnancies is related to the age of menopause[21-24, 2629]. However, our study shows that there is no correlation between the times of fertility and the age of menopause. After analysis, the reason may be related to the strict family planning in China since the early 1980s. Due to the strict implementation of the family planning policy, the majority of participants had only one child, which may limit our results. As the birth policy changes, the relationship between the number of pregnancies and the age of menopause may also change. Further research is needed.

This study is an initial summary of menopausal age and possible influencing factors of women in urban districts in China. Nevertheless, there are some limitations. First, there was an insufficient sample size and limited sources of respondents with comparison of about 1.4 billion Chinese populations. These both may have introduced bias. Second, there was an incomplete consideration of influencing factors, since not all factors that may affect menopausal age were analyzed, such as education level and economic status. Therefore, future research should include women with a larger geographical distribution and a larger sample size that considers more potential influencing factors.

\section{Conclusions}

This study showed that the average age of natural menopause was $49.49 \pm 3.67$ years old in provinces in China. Weight, menarche age, marital status, drinking tea or not (often and daily), eating supplements, oral contraceptive contraception, and safe contraception are all factors that could influence the age of natural menopause. Thus, women should pay attention to these factors to keep the age of natural menopause in the normal scope to avoid relevant diseases. 


\section{Declarations}

\section{- Ethics approval and consent to participate}

We obtained informed consent from the participants by written or verbal and obtained approval from the Guilin Medical college ethics review committees to conduct this research.

\section{- Consent to publish}

We all agree to publish this paper.

\section{- Availability of data and materials}

The data in this paper can be available freely.

\section{- Competing interests}

The authors have declared that no competing interests exist. This work was supported by the Guangxi Natural Science Foundation (grant no. GUIKEAD19110071), the National Natural Science Foundation of China (grant no. 81470110), and the Guangxi College Students' Innovative Entrepreneurial Training Plan Program (grant nos. 20190601019, 20190601017, and 20190601098). This study was also supported by High-level Hospital Construction Research Project of Maoming People's Hospital.

\section{- Funding}

This work was supported by the Guangxi Natural Science Foundation (grant no. GUIKEAD19110071), the National Natural Science Foundation of China (grant no. 81470110), and the Guangxi College Students' Innovative Entrepreneurial Training Plan Program (grant nos. 20190601019, 20190601017, and 20190601098). This study was also supported by High-level Hospital Construction Research Project of Maoming People's Hospital.

\section{- Authors' Contributions}

Xuming Wang and Huawei Gui were responsible for thesis writing and experimental design. Chunyan Yuan and Lijiang Liu were responsible for data processing. Jianguo Wei, Helin Huang, Zhaohui Qiu, and Xiaolu Yuan performed the data collection. All authors read and approved the final manuscript.

\section{- Acknowledgements}

This work was supported by the Guangxi Natural Science Foundation (grant no. GUIKEAD19110071), the National Natural Science Foundation of China (grant no. 81470110), and the Guangxi College Students' Innovative Entrepreneurial Training Plan Program (grant nos. 20190601019, 20190601017, and 20190601098). This study was also supported by High-level Hospital Construction Research Project of Maoming People's Hospital. 


\section{References}

1. Wheater G, Elshahaly M, Tuck SP, Datta HK, van Laar JM. The clinical utility of bone marker measurements in osteoporosis. Journal of translational medicine. 2013;11:201.

2. Yang XR, Figueroa JD, Hewitt SM, Falk RT, Pfeiffer RM, Lissowska J, Peplonska B, Brinton LA, GarciaClosas $M$, Sherman ME. Estrogen receptor and progesterone receptor expression in normal terminal duct lobular units surrounding invasive breast cancer. Breast cancer research treatment. 2013;137(3):837-47.

3. Oh H, Eliassen AH, Wang M, Smith-Warner SA, Beck AH, Schnitt SJ, Collins LC, Connolly JL, Montaser-Kouhsari L, Polyak K, et al: Expression of estrogen receptor, progesterone receptor, and $\mathrm{Ki} 67$ in normal breast tissue in relation to subsequent risk of breast cancer. NPJ breast cancer 2016, 2.

4. Carlisle SM, Hein DW. Retrospective analysis of estrogen receptor 1 and Nacetyltransferase gene expression in normal breast tissue, primary breast tumors, and established breast cancer cell lines. Int J Oncol. 2018;53(2):694-702.

5. Oh H, Eliassen AH, Beck AH, Rosner B, Schnitt SJ, Collins LC, Connolly JL, Montaser-Kouhsari L, Willett WC, Tamimi RM. Breast cancer risk factors in relation to estrogen receptor, progesterone receptor, insulin-like growth factor-1 receptor, and Ki67 expression in normal breast tissue. NPJ breast cancer. 2017;3:39.

6. Treeck O, Diepolder E, Skrzypczak M, Schuler-Toprak S, Ortmann O. Knockdown of estrogen receptor beta increases proliferation and affects the transcriptome of endometrial adenocarcinoma cells. BMC Cancer. 2019;19(1):745.

7. Li YM, Zhang YB, Yang HL. Gprotein-coupled estrogen receptor 30 and extracellular signal-regulated kinase 1/2 in endometrial adenocarcinoma. J Biol Regul Homeost Agents. 2019;33(2):421-6.

8. Guan J, Xie L, Luo X, Yang B, Zhang H, Zhu Q, Chen X. The prognostic significance of estrogen and progesterone receptors in grade I and II endometrioid endometrial adenocarcinoma: hormone receptors in risk stratification. Journal of gynecologic oncology. 2019;30(1):e13.

9. Maekawa R, Mihara Y, Sato S, Okada M, Tamura I, Shinagawa M, Shirafuta Y, Takagi H, Taketani T, Tamura $\mathrm{H}$, et al. Aberrant DNA methylation suppresses expression of estrogen receptor 1 (ESR1) in ovarian endometrioma. Journal of ovarian research. 2019;12(1):14.

10. Ataei N, Aghaei M, Panjehpour M. Evidences for involvement of estrogen receptor induced ERK1/2 activation in ovarian cancer cell proliferation by Cadmium Chloride. Toxicology in vitro: an international journal published in association with BIBRA. 2019;56:184-93.

11. Cabelka CA, Baumann CW, Collins BC, Nash N, Le G, Lindsay A, Spangenburg EE, Lowe DA. Effects of ovarian hormones and estrogen receptor alpha on physical activity and skeletal muscle fatigue in female mice. Experimental gerontology. 2019;115:155-64.

12. Lee SJ, Kim TW, Park GL, Hwang YS, Cho HJ, Kim JT, Lee HG. G protein-coupled estrogen receptor-1 agonist induces chemotherapeutic effect via ER stress signaling in gastric cancer. BMB Rep. 
2019;52(11):647-52.

13. Tian S, Zhan N, Li R, Dong W. Downregulation of G Protein-Coupled Estrogen Receptor (GPER) is Associated with Reduced Prognosis in Patients with Gastric Cancer. Medical science monitor: international medical journal of experimental clinical research. 2019;25:3115-26.

14. Kim JH, Choi YK, Byun JK, Kim MK, Kang YN, Kim SH, Lee S, Jang BK, Park KG: Estrogen-related receptor gamma is upregulated in liver cancer and its inhibition suppresses liver cancer cell proliferation via induction of p21 and p27. Experimental \& molecular medicine 2016, 48:e213.

15. Bleckmann A, Conradi LC, Menck K, Schmick NA, Schubert A, Rietkotter E, Arackal J, Middel P, Schambony $A$, Liersch T, et al: beta-catenin-independent WNT signaling and Ki67 in contrast to the estrogen receptor status are prognostic and associated with poor prognosis in breast cancer liver metastases. Clinical \& experimental metastasis 2016, 33(4):309-323.

16. Zhang B, Zhang CG, Ji LH, Zhao G, Wu ZY. Estrogen receptor beta selective agonist ameliorates liver cirrhosis in rats by inhibiting the activation and proliferation of hepatic stellate cells. Journal of gastroenterology hepatology. 2018;33(3):747-55.

17. Zhang CG, Zhang B, Deng WS, Duan M, Chen W, Wu ZY. Role of estrogen receptor beta selective agonist in ameliorating portal hypertension in rats with $\mathrm{CCl} 4$-induced liver cirrhosis. World journal of gastroenterology. 2016;22(18):4484-500.

18. Deng Y, Li L, Li C, Wang F, Qu Y. Efficacy of combined medication of risedronate sodium and selective estrogen receptor modulator on the postmenopausal osteoporosis. Pakistan journal of pharmaceutical sciences. 2020;33(1(Special)):495-8.

19. Xiang $\mathrm{D}, \mathrm{He} \mathrm{J}$, Jiang $\mathrm{T}$. The correlation between estrogen receptor gene polymorphism and osteoporosis in Han Chinese women. Eur Rev Med Pharmacol Sci. 2018;22(23):8084-90.

20. Gold EB. The timing of the age at which natural menopause occurs. Obstet Gynecol Clin N Am. 2011;38(3):425-40.

21. Henderson KD, Bernstein L, Henderson B, Kolonel L, Pike MC. Predictors of the timing of natural menopause in the Multiethnic Cohort Study. Am J Epidemiol. 2008;167(11):1287-94.

22. Mishra GD, Chung HF, Cano A, Chedraui P, Goulis DG, Lopes P, Mueck A, Rees M, Senturk LM, Simoncini T, et al. EMAS position statement: Predictors of premature and early natural menopause. Maturitas. 2019;123:82-8.

23. Wei XL, Hua YJ, Lu Y, Hu YH, Bian Z, Guo Y, Chen ZM, Li LM. [Impact of menarche age on the nearterm and long-term obesity of adult females]. Zhonghua liu xing bing xue za zhi = Zhonghua liuxingbingxue zazhi. 2019;40(2):142-6.

24. Huebner M, Meltzer DE, Perperoglou A. Age-associated Performance Decline and Sex Differences in Olympic Weightlifting. Med Sci sports Exerc. 2019;51(11):2302-8.

25. Bjelland EK, Hofvind S, Byberg L, Eskild A. The relation of age at menarche with age at natural menopause: a population study of 336788 women in Norway. Human reproduction. 2018;33(6):1149-57. 
26. Parazzini F, Progetto Menopausa Italia Study G. Determinants of age at menopause in women attending menopause clinics in Italy. Maturitas. 2007;56(3):280-7.

27. Li H, Sun X, Miller E, Wang Q, Tao P, Liu L, Zhao Y, Wang M, Qi Y, Li J: BMI, reproductive factors, and breast cancer molecular subtypes: A case-control study and meta-analysis. Journal of epidemiology 2017, 27(4):143-151.

28. Muka T, Oliver-Williams C, Kunutsor S, Laven JS, Fauser BC, Chowdhury R, Kavousi M, Franco OH: Association of Age at Onset of Menopause and Time Since Onset of Menopause With Cardiovascular Outcomes, Intermediate Vascular Traits, and All-Cause Mortality: A Systematic Review and Meta-analysis. JAMA cardiology 2016, 1(7):767-776.

29. Voorhuis M, Onland-Moret NC, van der Schouw YT, Fauser BC, Broekmans FJ. Human studies on genetics of the age at natural menopause: a systematic review. Hum Reprod Update. 2010;16(4):364-77.

\section{Tables}

Table $1 \otimes T h e$ analysis between the average age of natural menopause and related factors 


\begin{tabular}{|c|c|c|c|c|c|}
\hline Group & $\begin{array}{l}\text { Early } \\
\text { menopause }\end{array}$ & $\begin{array}{l}\text { Normal } \\
\text { menopause }\end{array}$ & $\begin{array}{l}\text { Late } \\
\text { menopause }\end{array}$ & $\begin{array}{l}\text { Chi- } \\
\text { square }\end{array}$ & $P$ \\
\hline Married or not & & & & 11.400 & 0.003 \\
\hline No & $8(2.4)$ & $19(0.5)$ & $1(0.6)$ & & \\
\hline Yes & $319(97.6)$ & 3908 (99.5) & $171(99.4)$ & & \\
\hline Frequency of drinking tea & & & & 18.005 & 0.006 \\
\hline Never & $123(37.6)$ & $1195(30.4)$ & $43(25.0)$ & & \\
\hline $\begin{array}{l}\text { Occasional (> once a month and } \\
<\text { once a week) }\end{array}$ & $134(41.0)$ & $1765(44.9)$ & $73(42.4)$ & & \\
\hline $\begin{array}{l}\text { Often (> once a week and <once a } \\
\text { day) }\end{array}$ & $47(14.4)$ & $751(19.1)$ & $45(26.2)$ & & \\
\hline$>=$ once a day & $23(7.0)$ & $216(5.5)$ & $11(6.4)$ & & \\
\hline Smoking frequency & & & & 48.471 & 0.000 \\
\hline Never & $291(89.0)$ & 3571 (90.9) & $125(72.7)$ & & \\
\hline $\begin{array}{l}\text { Occasional (> one pack a month and } \\
\text { <one pack a week) }\end{array}$ & $29(8.9)$ & $291(7.4)$ & $41(23.8)$ & & \\
\hline $\begin{array}{l}\text { Often (> one pack a week and <one } \\
\text { pack a day) }\end{array}$ & $5(1.5)$ & $51(1.3)$ & $3(1.7)$ & & \\
\hline$>=$ one pack a day & $2(0.6)$ & $14(0.4)$ & $3(1.7)$ & & \\
\hline Drinking frequency & & & & 26.309 & 0.000 \\
\hline Never & $212(64.8)$ & $2268(57.8)$ & $86(50.0)$ & & \\
\hline $\begin{array}{l}\text { Occasional }>100 \mathrm{ml} \text { per month and } \\
<100 \mathrm{ml} \text { per week }\end{array}$ & $88(26.9)$ & $1467(37.4)$ & $69(40.1)$ & & \\
\hline $\begin{array}{l}\text { Often> } 100 \mathrm{ml} \text { per week and }<100 \mathrm{ml} \\
\text { per day }\end{array}$ & $24(7.3)$ & $172(4.4)$ & $15(8.7)$ & & \\
\hline$>100 \mathrm{ml}$ per day & $3(0.9)$ & $20(0.5)$ & $2(1.2)$ & & \\
\hline Frequency of eating fruit & & & & 17.187 & 0.009 \\
\hline Never & $27(8.3)$ & $231(5.9)$ & $2(1.2)$ & & \\
\hline $\begin{array}{l}\text { Occasional> } 250 \mathrm{~g} \text { per month and } \\
<250 \mathrm{~g} \text { per week }\end{array}$ & $111(33.9)$ & $1535(39.1)$ & $79(45.9)$ & & \\
\hline $\begin{array}{l}\text { Often }>250 \text { g per week and }<250 \text { g per } \\
\text { day }\end{array}$ & $161(49.2)$ & 1780 (45.3) & $80(46.5)$ & & \\
\hline$>250$ g per day & $28(8.6)$ & $381(9.7)$ & $11(6.4)$ & & \\
\hline A vegetarian or not & & & & 1.472 & 0.479 \\
\hline
\end{tabular}




\begin{tabular}{|c|c|c|c|c|c|}
\hline Yes & $44(13.5)$ & $507(12.9)$ & $17(9.9)$ & & \\
\hline No & $283(86.5)$ & $\begin{array}{r}3420 \\
(87.1)\end{array}$ & $155(90.1)$ & & \\
\hline $\begin{array}{l}\text { Frequency of eating supplements } \\
\text { such as the donkey-hide gelatin }\end{array}$ & & & & 37.023 & 0.000 \\
\hline Never & $185(56.6)$ & 1935 (49.3) & $54(31.4)$ & & \\
\hline $\begin{array}{l}\text { Occasional (> once a month and } \\
\text { <once a week) }\end{array}$ & $122(37.3)$ & $1575(40.1)$ & $98(57.0)$ & & \\
\hline $\begin{array}{l}\text { Often (> once a week and <once a } \\
\text { day) }\end{array}$ & $19(5.8)$ & $376(9.6)$ & $16(9.3)$ & & \\
\hline >=once a day & $1(0.3)$ & $41(1.0)$ & $4(2.3)$ & & \\
\hline Sleep quality & & & & 23.098 & 0.001 \\
\hline Poor & $159(48.6)$ & $2364(60.2)$ & $110(64.0)$ & & \\
\hline Good & $168(51.4)$ & $1563(39.8)$ & $62(36.0)$ & & \\
\hline Contraception & & & & 32.109 & 0.000 \\
\hline Never use & $79(24.2)$ & $944(24.0)$ & $46(26.7)$ & & \\
\hline Oral contraceptive & $99(30.3)$ & $1155(29.4)$ & $53(30.8)$ & & \\
\hline Safe period & $99(303)$ & $1160(29.5)$ & $40(23.3)$ & & \\
\hline Condom & $4(1.2)$ & $282(7.2)$ & $6(3.5)$ & & \\
\hline ligation & $15(4.6)$ & $134(3.4)$ & $9(5.2)$ & & \\
\hline Intrauterine ring & $31(9.5)$ & $252(6.4)$ & $18(10.5)$ & & \\
\hline
\end{tabular}


Table 2. The Correlation analysis of all impacts

Impacts

(n)

\section{Non-standard coefficient}

B Standard
Standard coefficient
Significance

\begin{tabular}{|c|c|c|c|c|c|}
\hline & B & $\begin{array}{l}\text { Standard } \\
\text { error }\end{array}$ & Beta & & \\
\hline Fertility times & -.071 & .048 & -.024 & -1.476 & .140 \\
\hline 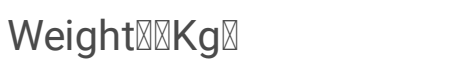 & -.018 & .003 & -.038 & -2.515 & .012 \\
\hline $\begin{array}{l}\text { Married or not } 0 \text { no } 1 \\
\text { yes }\end{array}$ & 2.587 & .697 & .056 & 3.711 & .000 \\
\hline Menarche age & .077 & .029 & .041 & 2.624 & .009 \\
\hline Drink tea occasionally & .198 & .139 & .027 & 1.418 & .156 \\
\hline Drink tea often & .863 & .169 & .092 & 5.101 & .000 \\
\hline Drink tea everyday & .914 & .256 & .058 & 3.577 & .000 \\
\hline $\begin{array}{l}\text { Drink wine } \\
\text { occasionally }\end{array}$ & .004 & .122 & .000 & .031 & .975 \\
\hline Drink wine often & -.479 & .263 & -.028 & -1.820 & .069 \\
\hline Drink wine everyday & -1.417 & .735 & -.029 & -1.928 & .054 \\
\hline Eat fruit occasionally & .026 & .249 & .004 & .106 & .916 \\
\hline Eat fruit often & -.214 & .257 & -.029 & -.835 & .404 \\
\hline Eat fruit everyday & -.439 & .305 & -.035 & -1.437 & .151 \\
\hline $\begin{array}{l}\text { Eat supplements } \\
\text { everyday }\end{array}$ & .418 & .133 & .056 & 3.156 & .002 \\
\hline Eat supplements often & .806 & .214 & .064 & 3.765 & .000 \\
\hline $\begin{array}{l}\text { Eat supplements } \\
\text { everyday }\end{array}$ & 1.548 & .557 & .043 & 2.778 & .005 \\
\hline Oral contraceptive & -.404 & .159 & -.050 & -2.539 & .011 \\
\hline Safe period & -.603 & .155 & -.075 & -3.896 & .000 \\
\hline Condom & .083 & .250 & .006 & .334 & .739 \\
\hline ligation & -.351 & .315 & -.018 & -1.115 & .265 \\
\hline Intrauterine ring & -.359 & .244 & -.025 & -1.469 & .142 \\
\hline Drink milk occasionally & -.153 & .143 & -.021 & -1.071 & .284 \\
\hline Drink milk often & .345 & .185 & .035 & 1.860 & .063 \\
\hline
\end{tabular}




\begin{tabular}{|llllll|} 
Drink milk everyday & .277 & .324 & .014 & .854 & .393 \\
\hline (constant) & 46.942 & .907 & & 51.738 & .000 \\
\hline
\end{tabular}

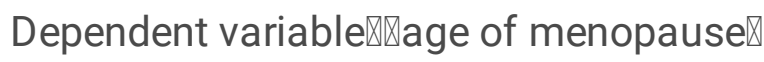

Table $3 \llbracket$ The logistic correlation regression analysis

\begin{tabular}{|llllll|}
\hline Group & $\begin{array}{l}\text { Early menopause } \\
\text { group }\end{array}$ & $\begin{array}{l}\text { Normal menopause } \\
\text { group }\end{array}$ & $\begin{array}{l}\text { Late menopause } \\
\text { group }\end{array}$ & $\mathrm{F}$ & $\mathrm{P}$ \\
\hline $\begin{array}{l}\text { Body } \\
\text { weight }\end{array}$ & $116.12 \pm 16.06$ & $113.49 \pm 15.77^{*}$ & $110.92 \pm 18.66^{*}$ & 6.648 & 0.001 \\
$\begin{array}{l}\text { Menarche } \\
\text { age }\end{array}$ & $13.82 \pm 2.26 \#$ & $13.97 \pm 1.90 \#$ & $14.37 \pm 2.37$ & 4.667 & 0.009 \\
\hline $\begin{array}{l}\text { Fertility } \\
\text { times }\end{array}$ & $2.39 \pm 1.17$ & $2.35 \pm 1.24$ & $2.38 \pm 1.28$ & 0.166 & 0.847 \\
\hline
\end{tabular}

Table 3 * Compared with the early menopause group, $\mathrm{P}<0.05$; \#Compared with the late menopause group, $\mathrm{P}<0.05$.

\section{Supplementary Files}

This is a list of supplementary files associated with this preprint. Click to download.

- STROBEChecklistv4combined.pdf 